\title{
PERAMPASAN DAN PENGEMBALIAN BARANG BUKTI ALAT ANGKUT TINDAK PIDANA ILLEGAL LOGGING DALAM MEWUJUDKAN RASA KEADILAN ( Studi Putusan di Pengadilan Negeri Kandangan, Kabupaten Hulu Sungai Selatan dan Pengadilan Negeri Purbalingga, Kabupaten Purbalingga )
}

\author{
Praditia Danindra \\ Hakim pada Pengadilan Negeri Purbalingga
}

\begin{abstract}
Studies of Decision Number 14/Pid.B/2006/PN.Kgn jo Number 37/PID/2006/PT.BJM shows that the judge was correct in sentencing, but on the evidence they have different opinions. Courts of first return of the evidence to its owner, while the appeals court that the evidence seized goods for the country. This appeals court decision in accordance with the provisions of Article 78 paragraph (15) of Law Number 41 Year 1999 on Forestry, the Supreme Guide of the Technical Judicial and Court Management in 2005 and the Circular of the Supreme Court (SEMA) No. 01 Year 2008. Here the Panel of Judges to act only as an oral (funnel) laws which in French is called "He boushe de la loi." In Decision Number 44/Pid.B/2009/PN.Pbg jo Number 371/Pid/2009/PT.Smg is already really good against the imposition of the penalty or against the evidence that is returned to the beneficiary even though this decision does not match the above rules. Thus, the High Court Judges Semarang sense of justice is more priority than legal certainty.
\end{abstract}

Keyword: sentencing, evidence, justice, legal certainty, illegal logging.

Abstrak

Studi terhadap Putusan Nomor 14/Pid.B/2006/PN.Kgn jo Nomor 37/PID/2006/PT.BJM menunjukkan bahwa hakim sudah benar dalam penjatuhan hukuman, akan tetapi terhadap barang bukti keduanya berbeda pendapat. Pengadilan tingkat pertama mengembalikan barang bukti kepada pemiliknya, sedangkan pengadilan banding merampas barang bukti itu untuk negara. Putusan pengadilan banding ini sesuai dengan ketentuan Pasal 78 ayat (15) Undang-Undang Nomor 41 Tahun 1999 tentang Kehutanan, Petunjuk Mahkamah Agung tentang Tehnis Yudisial dan Manajemen Peradilan Tahun 2005 dan Surat Edaran Mahkamah Agung ( SEMA ) Nomor 01 Tahun 2008. Disini Majelis Hakim bertindak hanya sebagai mulut (corong) undang-undang yang dalam bahasa Perancis dinamakan "la boushe de la loi". Pada Putusan Nomor 44/Pid.B/2009/PN.Pbg jo Nomor 371/Pid/2009/PT.Smg adalah sudah benar baik terhadap penjatuhan hukuman maupun terhadap barang bukti yang dikembalikan kepada yang berhak meski putusan ini tidak sesuai peraturan tersebut di atas. Dengan demikian maka Majelis Hakim Pengadilan Tinggi Semarang tersebut lebih mengutamakan rasa keadilan daripada kepastian hukum.

Kata Kunci: pemidanaan, barang bukti, keadilan, kepastian hukum, illegal logging.

Pendahuluan

Berbagai masalah tentang hutan (kehutanan), yang diantaranya illegal logging banyak terjadi, adanya barang bukti alat angkut yang dirampas untuk Negara dan yang dikembalikan kepada pemiliknya. Dalam Pasal 78 ayat (15) Undang-Undang Nomor 41 Tahun 1999 tentang Kehutanan, ditentukan bahwa semua hasil hutan dari hasil kejahatan dan pelanggaran dan atau alat-alat termasuk alat angkutnya yang dipergunakan untuk melakukan kejahatan dan atau pelanggaran sebagaimana dimaksud dalam paal ini dirampas untuk Negara. ${ }^{1}$

\footnotetext{
Hadi Setia Tunggal. 2002. Undang-Undang Nomor 41 Tahun 1999 Tentang Kehutanan. Jakarta: Harvarindo, hlm. 38.
} 
Dalam konteks barang bukti ini, Pasal 194 ayat (1) Kitab Undang-Undang Hukum Acara Pidana ( KUHAP) menentukan bahwa dalam hal putusan pemidanaan atau bebas atau lepas dari segala tuntutan hukum, pengadilan menetap-kan supaya barang bukti yang disita diserahkan kepada pihak yang paling berhak menerima kembali yang namanya tercantum dalam putusan tersebut kecuali jika menurut ketentuan undang-undang barang bukti itu harus dirampas untuk kepentingan negara atau dimusnahkan atau dirusak sehingga tidak dapat dipergunakan lagi.

Pada putusan Pengadilan Negeri Kandangan Kabupaten Hulu Sungai Selatan dan Pengadilan Negeri Purbalingga Kabupaten Purbalingga dalam kasus tindak pidana illegal logging, dalam perkara Nomor 14/Pid.B/2006/PN. Kgn dan perkara Nomor 44/Pid.B/2009/PN.Pbg dimana dalam amar putusannya mengembalikan barang bukti alat angkut kepada pihak yang paling berhak (pemiliknya) dalam tindak pidana illegal logging, bukan dirampas untuk Negara.

Artikel ini akan membahas tentang aplikasi (pelaksanaan) dari Pasal 78 ayat (15) UndangUndang Nomor 41 Tahun 1999 tentang Kehutanan, Petunjuk Mahkamah Agung tentang Tehnis Yudisial dan Manajemen Peradilan Tahun 2005, Surat Edaran Mahkamah Agung (SEMA) Nomor 01 Tahun 2008 tentang Petunjuk Penanganan Perkara Tindak Pidana Kehutanan, Pasal 194 ayat (1) Kitab Undang-Undang Hukum Acara Pidana (KUHAP) di Pengadilan Negeri Kandangan Kabupaten Hulu Sungai Selatan dan Pengadilan Negeri Purbalingga Kabupaten Purbalingga secara yuridis normatif berkaitan dengan persoalan perampasan dan pengembalian barang bukti alat angkut tindak pidana illegal logging dalam mewujudkan rasa keadilan.

\section{Permasalahan}

Ada dua permasalahan yang hendak di bahas pada artikel ini. Pertama, kajian tentang pertimbangan Hakim di Pengadilan Negeri Kandangan Kabupaten Hulu Sungai Selatan dan Pengadilan Negeri Purbalingga Kabupaten Purbalingga dalam menjatuhkan putusan perampasan dan pengembalian barang bukti alat angkut dalam tindak pidana illegal logging; dan kedua, adalah kajian tentang pertimbangan Hakim di Pengadilan Negeri Kandangan Kabupaten Hulu Sungai Selatan dan Pengadilan Negeri Purbalingga Kabupaten Purbalingga dalam memutus perampasan dan pengembalian barang bukti alat angkut tindak pidana illegal logging merupakan wujud rasa keadilan.

\section{Metode Penelitian}

Metode pendekatan yang digunakan dalam penelitian ini adalah metode pendekatan yuridis normatif dengan tipe deskriptif kualitatif. Lokasi penelitian di Pengadilan Negeri Kandangan Kabupaten Hulu Sungai Selatan dan Pengadilan Negeri Purbalingga Kabupaten Purbalingga. Sumber data yang dipergunakan adalah data primer dan data sekunder. Data primer diper-oleh melalui wawancara dan data sekunder diperoleh melalui studi pustaka. Data yang di peroleh disajikan dalam bentuk uraian yang sistematis, rasional dan logis, yang selanjutkan dianalisis dengan analisis kualitatif.

\section{Pembahasan}

Pertimbangan Hakim dalam Putusan Pengadilan Negeri Kandangan, Kabupaten Hulu Sungai Selatan Nomor : 14/Pid.B/2006/PN.Kgn.

Sebelum membicarakan masalah pemidanaan sebaiknya kita mengetahui terlebih dahulu tentang apa yang sebenarnya dimaksud pidana itu sendiri. Menurut van Hamel, arti dari pidana atau straf menurut hukum positif dewasa ini adalah suatu penderitaan yang bersifat khusus, yang telah dijatuhkan oleh kekuasaan yang berwenang untuk menjatuhkan pidana atas nama negara sebagai penanggung jawab dari ketertiban hukum umum bagi seorang pelanggar, yaitu semata-mata karena orang tersebut telah melanggar suatu peraturan hukum yang harus ditegakkan oleh negara. ${ }^{2}$

Berkaitan dengan masalah pemidanaan Muladi, memberikan pengertian pemidanaan di lihat dari aspek penegakan hukum. Menurutnya, pidana dapat dilihat sebagai bagian dari mekanisme penegakan hukum (pidana) maka

2 P.A.F. Lamintang, 1984, Hukum Penitersier Indonesia. Bandung: Amrico, hlm. 47. 
"pemidanaan" yang biasa juga diartikan "pemberian pidana" tidak lain merupakan suatu proses kebijakan yang direncanakan. Artinya pemberian pidana itu untuk benar-benar dapat terwujud direncanakan melalui beberapa tahap yaitu, pertama, tahap penetapan pidana oleh pembuat undang-undang; kedua, tahap pemberian pidana oleh badan yang berwenang; dan ketiga, tahap pelaksanaan pidana oleh instansi pelaksana yang berwenang. Dilihat sebagai suatu proses mekanisme penegakan hukum pidana, maka ketiga tahapan pidana itu diharapkan merupakan satu jalinan mata rantai yang saling berkaitan dalam satu kebulatan sistem. ${ }^{3}$

Terdapat beberapa sistem pemidanaan yang diatur Undang-Undang Nomor 41 Tahun 1999 Tentang Kehutanan, Undang-undang Nomor 5 Tahun 1990 Tentang Konservasi Sumberdaya Alam Hayati Dan Ekosistemnya, Peraturan Pemerintah Republik Indonesia Nomor 28 Tahun 1985 Tentang Perlindungan Hutan, KUHP, Undang-Undang Nomor 20 Tahun 2001 Tentang Pemberantasan Tindak Pidana Korupsi, UndangUndang Nomor 32 Tahun 2009 Tentang Perlindungan dan Pengelolaan Lingkungan Hidup.

Sedangkan tindak pidana adalah perbuatan melakukan atau tidak melakukan sesuatu yang oleh peraturan perundang-undangan dinyatakan sebagai perbuatan yang dilarang dan diancam dengan pidana. Penebangan liar (illegal logging) adalah kegiatan di bidang kehutanan atau yang merupakan rangkaian kegiatan yang mencakup penebangan, pengangkutan, pengolahan hingga kegiatan jual beli (ekspor-impor) kayu yang tidak sah atau bertentangan dengan aturan hukum yang berlaku, atau perbuatan yang dapat menimbulkan kerusakan hutan.

Selanjutnya untuk tindak pidana illegal logging yang banyak dipergunakan adalah ketentuan dan sanksi yang terdapat dalam UndangUndang Nomor 41 Tahun 1999 Tentang Kehutanan. Dari ketentuan Pasal 78 ayat (15) UndangUndang Nomor 41 Tahun 1999 tentang Kehutanan dapat diketahui bahwa pidana perampasan barang-barang tertentu yang dipergunakan untuk melakukan tindak pidana kehutanan (illegal

3 Muladi, 2005, Teori-teori dan Kebijakan Pidana, Bandung: Alumni, hlm. 91. logging), yang dianut dalam undang-undang tersebut adalah bersifat kumulatif. Kumulatif artinya bahwa pidana perampasan terhadap barang-barang tertentu berupa semua "hasil hutan" dari hasil tindak pidana kehutanan (illegal logging) dapat dijatuhkan bersama-sama dengan perampasan alat-alat termasuk alat angkutnya yang dipergunakan untuk melakukan tindak pidana kehutanan (illegal logging). Terhadap persoalan penjatuhan pidana perampasan barang-barang tertentu dalam penerapan pidana dalam tindak pidana kehutanan terdapat Petunjuk Mahkamah Agung tentang Tehnis Yudisial dan Manajemen Peradilan Tahun 2005 yang ditujukan pada Peradilan Umum Pidana, yang antara lain menyebutkan bahwa tentang bukti dalam perkara illegal logging dinyatakan bahwa "barang bukti termasuk alat yang dipakai harus dirampas untuk Negara" (sifatnya imperatf), demikian juga yang terdapat dalam Surat Edaran Mahkamah Agung (SEMA) Nomor 01 Tahun 2008 tentang Petunjuk Penanganan Perkara Tindak Pidana Kehutanan, dinyatakan bahwa "Mahkamah Agung memandang perlu untuk mengingatkan para Hakim di seluruh Indonesia agar memperhatikan dengan sungguh-sungguh Pasal 78 ayat (15) Undang-Undang Nomor 41 Tahun 1999".

Dalam konteks barang bukti ini, Pasal 194 ayat (1) KUHAP ditentukan bahwa dalam hal putusan pemidanaan atau bebas atau lepas dari segala tuntutan hukum, pengadilan menetapkan supaya barang bukti yang disita diserahkan kepada pihak yang paling berhak menerima kembali yang namanya tercantum dalam putusan tersebut kecuali jika menurut ketentuan undang-undang barang bukti itu harus dirampas untuk kepentingan negara atau dimusnahkan atau dirusak sehingga tidak dapat dipergunakan lagi.

Selanjutnya akan dibahas putusan di Pengadilan Negeri Kandangan Kabupaten Hulu Sungai Selatan yaitu Putusan dalam kasus tindak pidana illegal logging, dalam perkara Nomor 14/Pid.B/2006/PN.Kgn., tanggal 7 Maret 2006, yang amarnya sebagai berikut.

Pertama, menyatakan terdakwa MUHAMMAD YANI Bin DURABI (Alm) telah terbukti 
secara sah dan meyakinkan bersalah melakukan tindak pidana "mengangkut hasil hutan yang tidak dilengkapi bersama-sama dengan Surat Keterangan Sahnya Hasil Hutan". Kedua, menghukum terdakwa oleh karena itu dengan pidana penjara selama 7 (tujuh) bulan dan denda sebesar Rp.500.000,- (lima ratus ribu rupiah) dengan ketentuan apabila denda tersebut tidak dibayar diganti dengan pidana kurungan selama 1 (satu) bulan. Ketiga, menetapkan bahwa masa selama terdakwa ditangkap dan atau menjalani tahanan sementara dikurangkan sepenuhnya dengan pidana tersebut.

Keempat, memerintahkan terdakwa tetap dalam tahanan Rumah Tahanan Negara. Kelima, memerintahkan barang bukti berupa (1) Potongan kayu jenis Ulin sebanyak 134 (se-ratus tiga puluh empat) dengan volume $2,5 \mathrm{~m} 3$ (dua setengah meter kubik) yang terdiri dari (a) 26 (dua puluh enam) potong dengan panjang 2 (dua) meter, tebal 10 (sepuluh) $\mathrm{cm}$, lebar 10 (sepuluh) $\mathrm{cm}$ dengan volume $0,5200 \mathrm{~m} 3$, (b) 65 (enam puluh lima) potong dengan panjang 3 (tiga) meter, tebal 10 (sepuluh) $\mathrm{cm}$, lebar 10 (sepuluh) $\mathrm{cm}$ dengan volume $1,9500 \mathrm{~m} 3$, (c) 35 (tiga puluh lima) potong dengan panjang 3 (tiga) meter, tebal 5 (lima) $\mathrm{cm}$, lebar 10 (sepuluh) $\mathrm{cm}$ dengan volume $0,5250 \mathrm{~m} 3$, (d) 8 (delapan) potong dengan panjang 2 (dua) meter, tebal 5 (lima) $\mathrm{cm}$, lebar 10 (sepuluh) $\mathrm{cm}$ dengan volume 0,0800 m3 dirampas untuk $\mathrm{Ne}$ gara; (2) Kendaraan dump truk Rino No.Pol : KT 8667 AN, dikembalikan kepada pemiliknya SABARUDDIN; dan (3) Menghukum terdakwa untuk membayar biaya perkara sebesar Rp.5.000,(lima ribu rupiah).

Menurut hemat penulis Putusan Nomor : 14/Pid.B/2006/PN.Kgn adalah sudah benar baik terhadap penjatuhan hukuman maupun terhadap barang bukti alat angkut kendaraan dump truk No.Pol: KT 8667 AN karena kendaraan dump truk No.Pol: KT 8667 AN dikembalikan kepada pemiliknya yaitu Sabaruddin meskipun hal ini tidak sesuai dengan ketentuan Pasal 78 ayat (15) Undang-Undang Nomor 41 Tahun 1999 tentang Kehutanan, Petunjuk Mahkamah Agung tentang Tehnis Yudisial dan Manajemen Peradilan Tahun 2005 dan Surat Edaran Mahkamah Agung ( SEMA)
Nomor 01 Tahun 2008 tentang Petunjuk Penanganan Perkara Tindak Pidana Kehutanan yang pada pokoknya menyatakan bahwa "barang bukti termasuk alat yang dipakai harus dirampas untuk Negara".

\section{Pertimbangan Hakim pada Putusan PT Banjar- masin Nomor 37/PID/2006/PT.BJM.}

Meskipun Putusan Nomor 14/Pid.B/2006/

PN.Kgn menurut Majelis Hakim dipandang telah memenuhi rasa keadilan, akan tetapi ternyata hal tersebut belumlah adil bagi Penuntut Umum dengan adanya pernyataan banding dihadapan Panitera Pengadilan Negeri Kandangan pada 09 Maret 2006 sebagaimana ternyata dari akta per-mintaan banding Nomor 39/Akta.Pid/2006/ PN. Kgn dan oleh Pengadilan Tinggi Banjarmasin telah diputuskan dengan Putusan Nomor 37/PID/2006/PT.BJM yang amarnya menyatakan. Pertama, menerima permintaan banding dari Jaksa Penuntut Umum; kedua, mengubah putusan Pe-ngadilan Negeri Kandangan tanggal 07 Maret 2006 Nomor 14/Pid.B/2006/PN.Kgn sekedar mengenai status barang bukti berupa 1 (satu) unit dump truk Rino No.Pol: KT 8667 AN sehingga amar putusannya sebagai berikut, (a) Menyatakan barang bukti berupa 1 (satu) unit dump truk Rino No.Pol: KT 8667 AN Dirampas untuk Negara; (b) Menguatkan Putusan Pengadilan Negeri Kandangan selain dan selebihnya; (c) Memerintahkan agar terdakwa tetap berada dalam tahanan; (d) Membebankan biaya perkara kepada terdakwa dalam kedua tingkat peradilan yang untuk tingkat banding sebesar Rp.2.500,- (dua ribu lima ratus rupiah).

Menurut hemat penulis Putusan Nomor 37/PID/2006/PT.BJM adalah sudah benar terhadap penjatuhan hukumannya tetapi terhadap barang bukti alat angkut tidak benar karena rasa keadilan tidak terwujud, kendaraan dump truk No.Pol: KT 8667 AN tidak dikembalikan kepada yang paling berhak (pemiliknya) yaitu Sabaruddin tetapi dirampas untuk Negara walau pun dalam pertimbangan Majelis Hakim Pengadilan Tinggi Banjarmasin sesuai dengan ketentuan Pasal 78 ayat (15) Undang-Undang Nomor 41 Tahun 1999 tentang Kehutanan, Petunjuk Mahkamah Agung tentang Tehnis Yudisial 
dan Manajemen Peradilan Tahun 2005 dan Surat Edaran Mahkamah Agung ( SEMA ) Nomor 01 Tahun 2008. Disini walaupun Majelis Hakim telah melaksanakan tugas "pembentukan hukum" akan tetapi hanya menempatkan hakim semata-mata "menempelkan" atau "memberikan tempat" suatu peristiwa hukum dengan ketentuan-ketentuan yang ada atau dapat di katakan menerapkan hukum apa adanya (rechtstoepassing), Majelis Hakim bertindak hanya sebagai mulut (corong) undang-undang yang dalam bahasa Perancis dinamakan "la boushe de la loi".

Pertimbangan Hakim dalam Putusan Pengadilan Negeri Purbalingga Nomor: 44/Pid.B/ 2009/PN.Pbg.

Pengadilan Negeri Purbalingga Kabupaten Purbalingga telah menjatuhkan putusan dalam kasus tindak pidana illegal logging, dalam perkara Nomor 44/Pid.B/2009/PN.Pbg tanggal 1 Juni 2009, yang amarnya sebagai berikut. Pertama, menyatakan terdakwa NURUDIN Bin RUSYADI, telah terbukti secara sah dan meyakinkan bersalah melakukan tindak pidana "bersamasama mengangkut hasil hutan yang tidak dilengkapi bersama-sama dengan surat keterangan sahnya hasil hutan"; kedua, menjatuhkan pidana kepada terdakwa oleh karena itu dengan pidana penjara selama 5 (lima) bulan dan denda sebesar Rp. 500.000,- (lima ratus ribu rupiah) dengan ketentuan apabila denda tersebut tidak dibayarkan akan diganti dengan pidana kurungan selama 1 (satu) bulan; ketiga, menetapkan lamanya terdakwa berada dalam tahanan di kurangkan seluruhnya dari pidana yang dijatuhkan; keempat, memerintahkan agar terdakwa dibebaskan dari tahanan; kelima, memerintahkan agar barang bukti, berupa (1) 19 (sembilan belas) batang kayu pinus panjang masing-masing $280 \mathrm{~cm} \quad(2,10) M^{3}$, dikembalikan kepada Perhutani KPH wilayah Banyumas Timur, (2) 1 (satu) unit Kbm Suzuki ST 150 Pick Up No Pol R1935-NC, Noka: MHYE14152J120374, Nosin: G15A JA120374, tahun 2002 berikut STNKnya dan Buku Kir An. Herbangun Susilo alamat Desa Karangjambu RT.09 RW.03 Kecamatan Karangjambu Kabupaten Purbalingga; Dikembalikan kepada
Chotijah, istri dari Almarhum Herbangun Susilo (a) 1 (satu) buah gergaji jenis gongsrang dengan panjang $74 \mathrm{~cm}$ yang pada kedua ujungnya bertangkai kayu, dan (b) 1 (satu) buah kampak ber-tangkai kayu kopi dengan panjang $50 \mathrm{~cm}$, di rusak sehingga tidak dapat dipergunakan lagi; dan keenam, membebankan kepada terdakwa untuk membayar biaya perkara sebesar Rp. 2.500,- (dua ribu lima ratus rupiah).

Menurut hemat penulis Putusan Nomor 44/Pid.B/2009/PN.Pbg adalah sudah benar baik terhadap penjatuhan hukuman maupun terhadap barang bukti alat angkut 1 (satu) unit mobil Suzuki Carry 1,5 jenis Pick Up tahun 2002 warna Hitam, Nomor Polisi R-1935-NC, Nomor Rangka MHYESL4152J120374, Nomor Mesin G15 AIA1203 74, 1 (satu) buah Buku Kir dan 1 (satu) buah STNK dikembalikan kepada yang paling berhak yaitu Chotijah sebagai istri dari almarhum Herbangun Susilo, meskipun hal ini tidak sesuai dengan ketentuan Pasal 78 ayat (15) Undang-Undang Nomor 41 Tahun 1999 tentang Kehutanan, Petunjuk Mahkamah Agung tentang Tehnis Yudisial dan Manajemen Peradilan Tahun 2005 dan Surat Edaran Mahkamah Agung (SEMA) Nomor 01 Tahun 2008 tentang Petunjuk Penanganan Perkara Tindak Pidana Kehutanan yang pada pokoknya menyatakan bahwa "barang bukti termasuk alat yang dipakai harus dirampas untuk Negara".

\section{Pertimbangan Hakim dalam Putusan PT. Semarang Nomor 371/Pid/2009/PT.Smg. \\ Putusan Nomor 44/Pid.B/2009/PN.Pbg} menurut Majelis Hakim dipandang telah memenuhi rasa keadilan, akan tetapi ternyata hal tersebut belumlah adil bagi Penuntut Umum dengan adanya permintaan banding yang dibuat dan ditanda tangani oleh Panitera Pengadilan Negeri Purbalingga yang isinya menerangkan bahwa pada tanggal 01 Maret 2009 Jaksa Penuntut Umum mengajukan pemeriksaan banding terhadap Putusan Pengadilan Negeri Purbalingga Nomor : 44/Pid.B/2009/PN.Pbg dan oleh Pengadilan Tinggi Semarang telah diputuskan dengan Putusan Nomor 371/Pid/2009/PT. Smg. yang amarnya menyatakan sebagai berikut. 
Pertama, menerima permintaan banding dari Jaksa Penuntut Umum; kedua, memperbaiki putusan Pengadilan Negeri Purbalingga tanggal 01 Juni 2009 Nomor 44/Pid.B/2009/PN. $\mathrm{Pbg}$ yang dimintakan banding dengan perbaikan amar putusan dengan meniadakan butir 4 amar putusan sehingga selengkapnya sebagai berikut (a) Menyatakan terdakwa NURUDIN BIN RUSYADI, telah terbukti secara sah dan meyakinkan bersalah melakukan tindak pidana "bersamasama mengangkut hasil hutan yang tidak di lengkapi bersama-sama dengan surat keterangan sahnya hasil hutan"; (b) Menjatuhkan pidana kepada terdakwa oleh karena itu dengan pidana penjara selama 5 (lima) bulan dan denda Rp. 500.000 , - (lima ratus ribu rupiah) dengan ketentuan apabila denda tersebut tidak di bayarkan akan diganti dengan pidana kurungan selama 1 (satu) bulan; (c) Menetapkan lamanya terdakwa berada dalam tahanan dikurangkan seluruhnya dari pidana yang dijatuhkan; (d) Memerintahkan agar barang bukti, berupa (1) 19 (sembilan belas) batang kayu pinus panjang masing-masing $280 \mathrm{~cm}(2,10) \mathrm{M}^{3}$ dikembalikan kepada Perhutani $\mathrm{KPH}$ wilayah Banyumas Timur, (2) 1 (satu) unit Kbm Suzuki ST 150 Pick Up No Pol R-1935-NC, Noka MHYE14152J120374, Nosin: G15AJA120374, tahun 2002 berikut STNKnya dan Buku Kir An. Herbangun Susilo alamat Desa Ka-rangjambu RT.09 RW.03 Kecamatan Karangjambu Kabupaten Purbalingga, dikembalikan kepada Chotijah, istri dari Almarhum Herbangun Susilo, (3) 1 (satu) buah gergaji jenis gongsrang dengan panjang $74 \mathrm{~cm}$ yang pada kedua ujung-nya bertangkai kayu dan 1 (satu) buah kampak bertangkai kayu kopi dengan panjang $50 \mathrm{~cm}$, di rusak sehingga tidak dapat dipergunakan lagi; dan (e) Membebankan kepada terdakwa untuk membayar biaya perkara dalam kedua tingkat peradilan yang dalam tingkat banding sebesar Rp.2.500,- (dua ribu lima ratus rupiah).

Menurut hemat penulis Putusan Nomor 371/Pid/2009/PT.Smg adalah sudah benar terhadap penjatuhan hukumannya maupun terhadap barang bukti alat angkut sehingga telah terwujud rasa keadilan, barang bukti alat angkut yang berupa 1 (satu) unit mobil Suzuki Carry 1,5 jenis Pick Up tahun 2002 warna Hitam, Nomor
Polisi R-1935-NC, Nomor Rangka MHYESL4152J1 20374, Nomor Mesin G15AIA120374, 1 (satu) buah Buku Kir dan 1 (satu) buah STNK dikembalikan kepada yang paling berhak yaitu Chotijah sebagai istri dari almarhum Herbangun Susilo tidak dirampas untuk kepentingan Negara, meskipun hal ini tidak sesuai dengan ketentuan $\mathrm{Pa}$ sal 78 ayat (15) Undang-Undang Nomor 41 Tahun 1999 tentang Kehutanan, Petunjuk Mahkamah Agung tentang Tehnis Yudisial dan Manajemen Peradilan Tahun 2005 dan Surat Edaran Mahkamah Agung (SEMA) Nomor 01 Tahun 2008 tentang Petunjuk Penanganan Perkara Tindak Pidana Kehutanan yang pada pokoknya menyatakan bahwa "barang bukti termasuk alat yang dipakai harus dirampas untuk Negara". Sedangkan perbaikan amar putusan dengan meniadakan butir 4 tersebut bukanlah terhadap barang buktinya. Dengan demikian maka Majelis Hakim Pengadilan Tinggi Semarang tersebut lebih mengutamakan rasa keadilan daripada kepastian hukum.

\section{Perwujudan Rasa Keadilan dalam Putusan Ha- kim dalam Putusan Perampasan dan Pengem- balian Barang Bukti Alat Angkut Tindak Pida- na Illegal Logging}

Putusan di Pengadilan Negeri Kandangan Kabupaten Hulu Sungai Selatan yaitu Putusan dalam kasus tindak pidana illegal logging, dalam perkara Nomor: 14/Pid.B/2006/PN.Kgn., tanggal 7 Maret 2006, amarnya menyatakan sebagai berikut.

Pertama, menyatakan terdakwa MUHAMMAD YANI Bin DURABI (Alm) telah terbukti secara sah dan meyakinkan bersalah melakukan tindak pidana "mengangkut hasil hutan yang tidak dilengkapi bersama-sama dengan Surat Keterangan Sahnya Hasil Hutan"; kedua, menghukum terdakwa oleh karena itu dengan pidana penjara selama 7 (tujuh) bulan dan denda sebesar Rp.500.000,- (lima ratus ribu rupiah) dengan ketentuan apabila denda tersebut tidak dibayar diganti dengan pidana kurungan selama 1 (satu) bulan; ketiga, Menetapkan bahwa masa selama terdakwa ditangkap dan atau menjalani tahanan sementara dikurangkan sepenuhnya dengan pidana tersebut; keempat, memerin- 
tahkan terdakwa tetap dalam tahanan Rumah Tahanan Negara.

Kelima, memerintahkan barang bukti berupa (1) Potongan kayu jenis Ulin sebanyak 134 (seratus tiga puluh empat) dengan volume 2,5 $\mathrm{m} 3$ (dua setengah meter kubik) yang terdiri dari (a) 26 (dua puluh enam) potong dengan panjang 2 (dua) meter, tebal 10 (sepuluh) $\mathrm{cm}$, lebar 10 (sepuluh) $\mathrm{cm}$ dengan volume 0,5200 m3; (b) 65 (enam puluh lima) potong dengan panjang 3 (tiga) meter, tebal 10 (sepuluh) $\mathrm{cm}$, lebar 10 (sepuluh) $\mathrm{cm}$ dengan volume $1,9500 \mathrm{m3}$; (c) 35 (tiga puluh lima) potong dengan panjang 3 (tiga) meter, tebal 5 (lima) cm, lebar 10 (sepuluh) $\mathrm{cm}$ dengan volume $0,5250 \mathrm{m3}$; (d) 8 (delapan) potong dengan panjang 2 (dua) meter, tebal 5 (lima) $\mathrm{cm}$, lebar 10 (sepuluh) $\mathrm{cm}$ dengan volume $0,0800 \mathrm{~m} 3$ dirampas untuk Negara; (e) Kendaraan dump truk Rino No.Pol : KT 8667 AN, dikembalikan kepada pemiliknya SABARUDDIN. Keenam, menghukum terdakwa untuk membayar biaya perkara sebesar Rp. 5.000,- lima ribu rupiah).

Menurut hemat penulis Putusan Nomor: 14/Pid.B/2006/PN.Kgn adalah sudah benar baik terhadap penjatuhan hukuman maupun terhadap barang bukti alat angkut kendaraan dump truk No.Pol : KT 8667 AN karena kendaraan dump truk No.Pol : KT 8667 AN dikembalikan kepada pemiliknya yaitu Sabaruddin meskipun hal ini tidak sesuai dengan ketentuan Pasal 78 ayat (15) Undang-Undang Nomor 41 Tahun 1999 tentang Kehutanan, Petunjuk Mahkamah Agung tentang Tehnis Yudisial dan Manajemen Peradilan Tahun 2005 dan Surat Edaran Mahkamah Agung ( SEMA) Nomor 01 Tahun 2008 tentang Petunjuk Penanganan Perkara Tindak Pidana Kehutanan yang pada pokoknya menyatakan bahwa "barang bukti termasuk alat yang dipakai harus dirampas untuk Negara".

Meskipun Putusan Nomor 14/Pid.B/2006/ PN.Kgn menurut Majelis Hakim dipandang telah memenuhi rasa keadilan, akan tetapi ternyata hal tersebut belumlah adil bagi Penuntut Umum dengan adanya pernyataan banding dihadapan Panitera Pengadilan Negeri Kandangan pada tanggal 09 Maret 2006 sebagaimana ternyata dari akta permintaan banding Nomor 39/Akta.
Pid/2006/PN.Kgn dan oleh Pengadilan Tinggi Banjarmasin telah diputuskan dengan Putusan Nomor 37/PID/2006/PT.BJM yang amarnya menyatakan menerima permintaan banding dari Jaksa Penuntut Umum; mengubah putusan Peng-adilan Negeri Kandangan tanggal 07 Maret 2006 Nomor 14/Pid.B/2006/PN.Kgn sekedar mengenai status barang bukti berupa 1 (satu) unit dump truk Rino No.Pol: KT 8667 AN sehingga amar putusannya sebagai berikut. Pertama, menyatakan barang bukti berupa 1 (satu) unit dump truk Rino No.Pol: KT 8667 AN dirampas untuk Negara; kedua, menguatkan Putusan Pengadilan Negeri Kandangan selain dan selebihnya; ketiga, memerintahkan agar terdakwa tetap berada dalam tahanan; keempat, membebankan biaya perkara kepada terdakwa dalam kedua tingkat peradilan yang untuk tingkat banding sebesar Rp.2.500,- (dua ribu lima ratus rupiah).

Menurut hemat penulis Putusan Nomor 37/PID/2006/PT.BJM adalah sudah benar terhadap penjatuhan hukumannya tetapi terhadap barang bukti alat angkut tidak benar karena rasa keadilan tidak terwujud, kendaraan dump truk No.Pol : KT 8667 AN tidak dikembalikan kepada yang paling berhak (pemiliknya) yaitu Sabaruddin tetapi dirampas untuk Negara walaupun dalam pertimbangan Majelis Hakim Pengadilan Tinggi Banjarmasin sesuai dengan ketentuan Pasal 78 ayat (15) Undang-Undang Nomor 41 Tahun 1999 tentang Kehutanan, Petunjuk Mahkamah Agung tentang Tehnis Yudisial dan Manajemen Peradilan Tahun 2005 dan Surat Edaran Mahkamah Agung (SEMA) Nomor 01 Tahun 2008. Disini walaupun Majelis Hakim telah melaksanakan tugas "pembentukan hukum" akan tetapi hanya menempatkan hakim semata-mata "menempelkan" atau "memberikan tempat" suatu peristiwa hukum dengan ketentuan-ketentuan yang ada atau dapat dikatakan menerapkan hukum apa adanya (rechtstoepassing), Majelis Hakim bertindak hanya sebagai mulut (corong) undang-undang yang dalam bahasa Perancis dinamakan "la boushe de la loi".

Terhadap putusan Pengadilan Negeri Purbalingga Kabupaten Purbalingga yaitu Putusan 
dalam kasus tindak pidana illegal logging, dalam perkara Nomor: 44/Pid.B/2009/PN.Pbg, menurut hemat penulis putusan tersebut adalah sudah benar baik terhadap penjatuhan hukuman mau pun terhadap barang bukti alat angkut 1 (satu) unit mobil Suzuki Carry 1,5 je-nis Pick Up tahun 2002 warna Hitam, Nomor Polisi R-1935-NC, Nomor Rangka MHYESL4152J1 20374, Nomor Mesin G15AIA120374, 1 (satu) buah Buku Kir dan 1 (satu) buah STNK di kembalikan kepada yang paling berhak yaitu Chotijah sebagai istri dari almarhum Herbangun Susilo, meskipun hal ini tidak sesuai dengan ketentuan Pasal 78 ayat (15) Undang-Undang Nomor 41 Tahun 1999 tentang Kehutanan, Pe-tunjuk Mahkamah Agung tentang Tehnis Yudi-sial dan Manajemen Peradilan Tahun 2005 dan Surat Edaran Mahkamah Agung (SEMA) Nomor 01 Tahun 2008 tentang Petunjuk Penanganan Perkara Tindak Pidana Kehutanan yang pada pokoknya menyatakan bahwa "barang bukti termasuk alat yang dipakai harus dirampas untuk Negara".

Putusan Nomor 44/Pid.B/2009/PN.Pbg menurut Majelis Hakim dipandang telah memenuhi rasa keadilan, akan tetapi ternyata hal tersebut belumlah adil bagi Penuntut Umum dengan adanya permintaan banding yang dibuat dan ditanda tangani oleh Panitera Pengadilan Negeri Purbalingga yang isinya menerangkan bahwa pada tanggal 01 Maret 2009 Jaksa Penuntut Umum mengajukan pemeriksaan banding terhadap Putusan Pengadilan Negeri Purbalingga Nomor 44/Pid.B/2009/PN.Pbg dan oleh Pengadilan Tinggi Semarang telah diputuskan dengan Putusan Nomor 371/Pid/2009/PT.Smg.

Menurut hemat penulis Putusan Nomor 371/Pid/2009/PT.Smg adalah sudah benar terhadap penjatuhan hukumannya maupun terhadap barang bukti alat angkut sehingga telah terwujud rasa keadilan, barang bukti alat angkut yang berupa 1 (satu) unit mobil Suzuki Carry 1,5 jenis Pick Up tahun 2002 warna Hitam, Nomor Polisi R-1935-NC, Nomor Rangka MHYESL4152J1 20374, No Mesin G15AIA120374, 1 (satu) buah Buku Kir dan 1 (satu) buah STNK dikembalikan kepada yang paling berhak yaitu Chotijah sebagai istri dari almarhum Herbangun Susilo tidak dirampas untuk kepentingan Negara, meskipun hal ini tidak sesuai dengan ketentuan Pasal 78 ayat (15) Undang-Undang Nomor 41 Tahun 1999 tentang Kehutanan, Petunjuk Mahkamah Agung tentang Tehnis Yudisial dan Manajemen Peradilan Tahun 2005 dan Surat Edaran Mahkamah Agung (SEMA) Nomor 01 Tahun 2008 tentang Petunjuk Penanganan Perkara Tindak Pidana Kehutanan yang pada pokoknya menyatakan bahwa "barang bukti termasuk alat yang di pakai harus dirampas untuk Negara". Sedangkan perbaikan amar putusan dengan meniadakan butir 4 tersebut bukanlah terhadap barang buktinya. Dengan demikian maka Majelis Hakim Peng-adilan Tinggi Semarang tersebut lebih mengutamakan rasa keadilan daripada kepastian hukum.

\section{Penutup \\ Simpulan}

Simpulan yang dapat diberikan berdasarkan uraian pembahasan di atas pada permasalahan yang pertama adalah sebagai berikut. Pertama, terhadap Pertimbangan Hakim dalam Putusan Pengadilan Negeri Kandangan, Kabupaten Hulu Sungai Selatan Nomor 14/Pid.B/ 2006/PN.Kgn. Barang bukti alat angkut berupa kendaraan dikembalikan kepada pemiliknya adalah sudah benar karena menurut pertimbangan Majelis Hakim Pengadilan Negeri Kandangan kendaraan tersebut bukan milik terdakwa namun milik pihak lain, demi keadilan dan melindungi kepentingan pihak ketiga meskipun hal ini tidak sesuai dengan ketentuan Pasal 78 ayat (15) Undang-Undang Nomor 41 Tahun 1999 tentang Kehutanan, Petunjuk Mahkamah Agung tentang Tehnis Yudisial dan Manajemen Peradilan Tahun 2005 dan Surat Edaran Mahkamah Agung (SEMA) Nomor 01 Tahun 2008 tentang Petunjuk Penanganan Perkara Tindak Pidana Kehutanan yang pada pokoknya menyatakan bahwa "barang bukti termasuk alat yang dipakai harus dirampas untuk Negara". Dengan demikian maka rasa keadilan telah terwujud dalam Putusan tersebut sesuai dengan teori keadilan kumutatif menurut Aristoteles yaitu suatu kebajikan untuk memberikan kepada setiap orang haknya atau sedekat mungkin dengan haknya. 
Kedua, terhadap Pertimbangan Hakim dalam Putusan Pengadilan Tinggi Banjarmasin Nomor 37/PID/2006/PT.BJM. Barang bukti alat angkut berupa kendaraan tidak dikembalikan kepada yang paling berhak (pemiliknya) tetapi dirampas untuk Negara, hal ini tidak benar karena rasa keadilan tidak terwujud walaupun dalam pertimbangan Majelis Hakim Pengadilan Tinggi Banjarmasin berdasarkan ketentuan $\mathrm{Pa}$ sal 78 ayat (15) Undang-Undang Nomor $41 \mathrm{Ta}$ hun 1999 tentang Kehutanan dan berdasarkan instruksi Ketua Mahkamah Agung Republik Indonesia pada Rakernas di Bali.

Ketiga, Pertimbangan Hakim dalam Putusan Pengadilan Negeri Purbalingga, Kabupaten Purbalingga Nomor 44/Pid.B/2009/PN.Pbg. Barang bukti alat angkut berupa 1 (satu) unit mobil dikembalikan kepada yang paling berhak, hal ini sudah benar karena dalam pertimbangan Majelis Hakim Pengadilan Negeri Purbalingga lebih menekankan kepada asas keadilan dari pada asas kepastian hukum (undang-undang)/ Contra Legem, dengan demikian maka rasa keadilan telah terwujud meskipun hal ini tidak sesuai dengan ketentuan Pasal 78 ayat (15) Undang-Undang Nomor 41 Tahun 1999 tentang Kehutanan, Petunjuk Mahkamah Agung tentang Tehnis Yudisial dan Manajemen Peradilan Tahun 2005 dan Surat Edaran Mahkamah Agung (SEMA) Nomor 01 Tahun 2008 tentang Petunjuk Penanganan Perkara Tindak Pidana Kehutanan yang pada pokoknya menyatakan bahwa "barang bukti termasuk alat yang dipakai harus dirampas untuk Negara".

Keempat, terhadap Pertimbangan Hakim dalam Putusan Pengadilan Tinggi Semarang Nomor 371/Pid/2009/PT.Smg. Barang bukti alat angkut berupa 1 (satu) unit mobil dikembalikan kepada yang paling berhak, tidak dirampas untuk kepentingan Negara, hal ini sudah benar karena kesimpulan dan pertimbangan hukum Pengadilan Negeri tersebut (Purbalingga) dapat disetujui dan dijadikan alasan dan pertimbangan hukum Pengadilan Tinggi sendiri dalam memutus perkara ini dalam tingkat banding sehingga rasa keadilan telah terwujud meskipun hal ini tidak sesuai dengan ketentuan Pasal 78 ayat (15) Undang-Undang Nomor 41 Tahun 1999 tentang
Kehutanan, Petunjuk Mahkamah Agung tentang Tehnis Yudisial dan Manajemen Peradilan Tahun 2005 dan Surat Edaran Mahkamah Agung (SEMA ) Nomor 01 Tahun 2008 tentang Petunjuk Pena-nganan Perkara Tindak Pidana Kehutanan yang pada pokoknya menyatakan bahwa barang bukti termasuk alat yang dipakai harus dirampas untuk Negara. Sedangkan perbaikan amar putusan dengan meniadakan butir 4 tersebut bukanlah terhadap barang buktinya. Dengan demikian maka Majelis Hakim Pengadilan Tinggi Semarang tersebut lebih mengutamakan rasa keadilan daripada kepastian hukum.

Terhadap permasalahan mengenai perwujudan Rasa Keadilan dalam Putusan Hakim dalam Putusan Perampasan dan Pengembalian Barang Bukti Alat Angkut Tindak Pidana Illegal Logging, dapat disimpulkan sebagai berikut. Pertama, Putusan Nomor 14/Pid.B/2006/PN. Kgn adalah sudah benar baik terhadap penjatuhan hukuman maupun terhadap barang bukti alat angkut kendaraan karena dikembalikan kepada pemiliknya meskipun hal ini tidak sesuai dengan ketentuan Pasal 78 ayat (15) Undang-Undang Nomor 41 Tahun 1999 tentang Kehutanan, Petunjuk Mahkamah Agung tentang Tehnis Yudisial dan Manajemen Peradilan Tahun 2005 dan Surat Edaran Mahkamah Agung (SEMA) Nomor 01 Tahun 2008 tentang Petunjuk Penanganan Perkara Tindak Pidana Kehutanan yang pada pokoknya menyatakan bahwa "barang bukti termasuk alat yang dipakai harus dirampas untuk Negara".

Kedua, Putusan Nomor 37/PID/2006/PT. BJM adalah sudah benar terhadap penjatuhan hukumannya tetapi terhadap barang bukti alat angkut tidak benar karena rasa keadilan tidak terwujud, kendaraan tidak dikembalikan kepada yang paling berhak (pemiliknya) tetapi dirampas untuk Negara walaupun dalam pertimbangan Majelis Hakim Pengadilan Tinggi Banjarmasin sesuai dengan ketentuan Pasal 78 ayat (15) Undang-Undang Nomor 41 Tahun 1999 tentang Kehutanan, Petunjuk Mahkamah Agung tentang Tehnis Yudisial dan Manajemen Peradilan Tahun 2005 dan SEMA Nomor 01 Tahun 2008. Disini walaupun Majelis Hakim telah melaksanakan tugas "pembentukan hukum" akan 
tetapi hanya menempatkan hakim semata-mata "menempelkan" atau "memberikan tempat" suatu peristiwa hukum dengan ketentuanketentuan yang ada atau dapat dikatakan menerapkan hukum apa adanya (rechtstoepassing), Majelis Hakim bertindak hanya sebagai mulut (corong) undang-undang yang dalam bahasa Perancis dinamakan "la boushe de la loi".

Ketiga, Putusan Nomor 44/Pid.B/2009/ PN.Pbg adalah sudah benar baik terhadap penjatuhan hukuman maupun terhadap barang bukti alat angkut 1 (satu) unit mobil dikembalikan kepada yang paling berhak, meskipun hal ini tidak sesuai dengan ketentuan Pasal 78 ayat (15) Undang-Undang Nomor 41 Tahun 1999 tentang Kehutanan, Petunjuk Mahkamah Agung tentang Tehnis Yudisial dan Manajemen Peradilan Tahun 2005 dan SEMA Nomor 01 Tahun 2008 tentang Petunjuk Penanganan Perkara Tindak Pidana Kehutanan yang pada pokoknya menyatakan bahwa "barang bukti termasuk alat yang dipakai harus dirampas untuk Negara".

Keempat, Putusan Nomor 371/Pid/2009/ PT.Smg adalah sudah benar terhadap penjatuhan hukumannya maupun terhadap barang bukti alat angkut sehingga telah terwujud rasa keadilan, barang bukti alat angkut yang berupa 1 (satu) unit mobil dikembalikan kepada yang paling berhak, tidak dirampas untuk kepentingan Negara meskipun hal ini tidak sesuai dengan ketentuan Pasal 78 ayat (15) Undang-Undang Nomor 41 Tahun 1999 tentang Kehutanan, Petunjuk Mahkamah Agung tentang Tehnis Yudisial dan Manajemen Peradilan Tahun 2005 dan SEMA No. 01 Tahun 2008 tentang Petunjuk Penanganan Perkara Tindak Pidana Kehutanan yang pada pokoknya menyatakan bahwa "barang bukti termasuk alat yang dipakai harus dirampas untuk Negara". Sedangkan perbaikan amar putusan dengan meniadakan butir 4 tersebut bukanlah terhadap barang buktinya. Dengan demikian maka Majelis Hakim Pengadilan Tinggi Semarang tersebut lebih mengutamakan rasa keadilan dari pada kepastian hukum.

\section{Saran}

Untuk mewujudkan rasa keadilan seharusnya dilakukan amandemen terhadap sistem pemidanaan khususnya Pasal 78 ayat (15) Undang-Undang Nomor 41 Tahun 1999 tentang Kehutanan, sehingga ada barang bukti alat angkut yang dirampas untuk Negara dan ada yang dikembali-kan kepada yang paling berhak (pemiliknya) terhadap semua hasil hutan dari hasil kejahatan dan pelanggaran dan atau alatalat termasuk alat angkut yang dipergunakan untuk melakukan kejahatan dan atau pelanggaran, tidak semuanya dirampas untuk Negara.

Petunjuk Mahkamah Agung tentang Tehnis Yudisial dan Manajemen Peradilan Tahun 2005 dan SEMA Nomor 01 Tahun 2008 tentang Petunjuk Penanganan Perkara Tindak Pidana Kehutanan yang pada pokoknya menyatakan bahwa "barang bukti termasuk alat yang dipakai harus dirampas untuk Negara", hanya sebagai petunjuk dari Mahkamah Agung dalam tindak pidana illegal logging, sehingga Hakim tidak harus mengikuti petunjuk tersebut dan tidak dapat mengintervensi Hakim dalam hal Perampasan dan Pengembalian Barang Bukti Alat Angkut Tindak Pidana illegal logging. 